\title{
Determination of Heavy Metals in Different Soils of Thi-Qar City
}

\author{
Shrrog Hammed Hlail \\ Department of Biology, College of Education for Pure Science, University of Thi-Qar, Iraq.
}

Correspondence Author: Shrrog Hammed Hlail, Department of Biology, College of Education for Pure Science, University of Thi-Qar, Iraq. E-mail: shrooq_hammed@yahoo.com

Received date: 20 July 2019, Accepted date: 15 September 2019, Online date: 30 September 2019

Copyright: (c) 2019 Shrrog Hammed Hlail. This is an open-access article distributed under the terms of the Creative Commons Attribution License, which permits unrestricted use, distribution, and reproduction in any medium, provided the original author and source are credited.

\begin{abstract}
The objective of this study was to estimate the content of heavy metals, physical and chemical properties in different soil. The samples were collected from two locations urban area (Nasiriyah city) and rural area (Agricultural lands close to the river Gharraf). Determination of heavy metals through zinc $(\mathrm{Zn})$, copper $(\mathrm{Cu})$ and lead $(\mathrm{Pb})$ were detected using an atomic absorption spectrometer (AAS). The results showed that the highest concentration of heavy metals in soil were found from the urban areas of Nasiriyah city. $\mathrm{Zn}$ and $\mathrm{Cu}$ were the most dominant metal whereas $\mathrm{Pb}$ had the lowest content for both soils. The results showed that urban samples had significantly $(\mathbf{p}<0.05)$ higher heavy metals compared to rural samples in all heavy metals studies. The physicochemical properties of soils studied (Ec., $\mathbf{p H}$ soil particles) showed significant differences $(\mathrm{p}<0.05)$ between the urban and rural areas. Variations in heavy metals content and physical and chemical properties in soil samples between locations indicating that locations play a more important role than soil structure and its physicochemical properties.
\end{abstract}

Keywords: Heavy metals, urban and rural area, physical and chemical properties

\section{INTRODUCTION}

The concentration of pollutants in the soil depends on the soil absorption properties of the elements [1]. The accumulation of heavy metals in the soil mainly affects several factors such as moisture content conductivity and pH. [2]. The main source of pollution of heavy elements in soil, water and air is the result of human activities, an increasing environmental problem affecting food quality and human health [3]. Soil is fundamental to a range of terrestrial ecosystems; it contains a scope of organic solids and minerals. Soils can contain especially high levels of heavy metals. However, upon extraction of heavy metals, these concentrations tend to increase further. Research has found that heavy metal contamination within a range of different soil types was the result of human action, such as sewage sludge, fertilizer use, pesticide action and water irrigation [4]. Heavy metals tend to exist as cations, under normal conditions, thereby producing soil sediments and colloid complexes, which tend to be negatively charged and contain particles of clay. Forming this complex is relatively slow, which may increase the risk of these metals become bioavailable for further contamination of soils or water sources, thereby affecting human activity [5, 6].

However,[4] discussed how metals are made bioavailable when the chemical processes that affect metal adsorption from a liquid to a solid are exerted. Metal ion concentrations and soil complexes affect this activity, which consequently alters their absorption via the root systems. A variety of different mechanisms can be applied to measure metal ion adsorption, such as specific adsorption, cation exchange/non-specific adsorption, insoluble precipitates of heavy metals in soils and co-precipitation and organic complex formation. Soil-bound metals form only a small part of the material that can be used for uptake by the plants [7]. Therefore, factors that affect speciation and concentration of metals within soils will ultimately determine their bioavailability to the plants. Metal-rich soils will produce plants that contain high degrees of metals. Their specific bioavailability relates to the factors affecting the soil quality, which include soil type, $\mathrm{pH}$, metal presence, redox potential (EH), plant factors, cation exchange capacity (CEC) and organic matter content. The aim of this study was to determine the effects of different habitat urban and rural areas on heavy metals and physical and chemical properties in Thi-Qar city, Iraq.

\section{Study Area}

\section{MATERIALS AND METHODS}

The samples of two different soils were collected from two sampling stations which were: (1) Nasiriyah city, (2) Agricultural lands close to the river Gharraf. For each sampling location, three samples replicate were taken $(n=3)$. 


\section{Soil Samples}

For the soil samples, a depth of $30 \mathrm{~cm}$ was dug from the surface of the soil to collect the samples. After the samples were collected, they were immediately placed in sealed plastic bags and labelled. The soil samples were then dried at air dry for 72 hours to remove all the moisture content. After drying, the samples were repeatedly crushed with clean mortar and pestle and sieved through a $250 \mu \mathrm{m}$ sieve to fineness. Collected soil samples were air-dried in the laboratory before being ground and sieved using a $250 \mu \mathrm{m}$ mash [5]. All the materials and tools used in this study were immersed in a solution of $10 \%$ nitric acid $\left(\mathrm{HNO}_{3}\right)$ for three days and rinsed twice with distilled water and with deionized water.

\section{Physical and Chemical properties of the Soil}

Soil pH, EC and particle size was determined. Physical and chemical properties of soil were determined according to methods by $[5,6]$.

\section{Statistical Analysis}

The heavy metals and physical and chemical properties for soils (urban and rural areas) were evaluated with the T-Test triplicates range test using SPSS software (SPSS ver.23). P values less than 0.05 were considered to be statistically significant [7].

\section{RESULTS AND DISCUSSION}

\section{Heavy Metals Content in the Soil}

The amount of $\mathrm{Zn}$ in the soil in urban area was higher than those in rural area as shown in Table1. The soil from Nasiriyah city showed the highest content of $\mathrm{Zn}(20.18 \mathrm{ug} / \mathrm{g})$. The $\mathrm{Zn}$ content in agricultural lands close to the river Gharraf is $12.36 \mathrm{ug} / \mathrm{g}$. General rural area low content of $\mathrm{Zn}$ in agricultural lands close to the river Gharraf compared to urban area. Comparing $\mathrm{Zn}$ concentration from this research and other published result is difficult because of the fact that concentration of zinc can be affected by extracting solvent, soil texture, depth and environment, [8, 9] reported that the zinc values for three different locations were informed between 0.38 to $3.40 \mathrm{mg} / \mathrm{kg}$. The total of $\mathrm{Zn}$ in the urban soil was lower its rural value in soil which shows that the total of zinc in this soil was in the safe level. The content of $\mathrm{Cu}$ in urban areas was higher compared with in rural areas. Among the metals studied, $\mathrm{Cu}$ was the metal found in the highest concentration at the two locations studied (Table 1). The $\mathrm{Cu}$ content was highest in Nasiriyah city soil follow by rural area 5.04 and $9.12 \mathrm{ug} / \mathrm{g}$ respectively. The Pb concentration in urban area was higher than those in rural area as shown in Table 1. 4.1. Between the soils studied, the Pb concentration in the two study areas were different. The highest $\mathrm{Pb}$ concentration was found in Nasiriyah city soil $14.50 \mathrm{ug} / \mathrm{g}$ and the lowest $\mathrm{Pb}$ concentration was in agricultural lands close to the river Gharraf $9.71 \mathrm{ug} / \mathrm{g}$. The reason maybe because of the high and low content of $\mathrm{Pb}$ probably depended mostly on the basic existing rock material in those particular areas. The presence of $\mathrm{Pb}$ content in urban a soil may come from traffic sources, especially pesticides, vehicle tires and motor vehicle emissions due to the location of this site just near a busy road and many vehicles go in and out from this location. According to [11, 12] the average $\mathrm{Pb}$ content of the soil from urban area $0.12-35 \mathrm{mg} / \mathrm{kg}$.

Table 1: Heavy metals content in the two soils of the study areas.

\begin{tabular}{|l|c|c|c|}
\hline \multirow{2}{*}{ Location } & \multicolumn{3}{|c|}{ Heavy metals (ug/g) } \\
\cline { 2 - 4 } & $\mathbf{Z n}$ & $\mathbf{C u}$ & $\mathbf{P b}$ \\
\hline Urban area & $20.18^{\mathrm{a}}$ & $9.12^{\mathrm{a}}$ & $14.50^{\mathrm{a}}$ \\
\hline Rural area & $12.36^{\mathrm{b}}$ & $5.04^{\mathrm{b}}$ & $9.71^{\mathrm{b}}$ \\
\hline p-value & 0.02 & 0.01 & 0.041 \\
\hline
\end{tabular}

${ }^{a-b}$ Mean with different letters are significantly different $(\mathrm{P}<0.05)$

\section{Physicochemical Properties of the Soil}

There are differences in physical and chemical properties $\left(\mathrm{pH}, \mathrm{Ec} . \mathrm{Mg}, \mathrm{Ca}, \mathrm{Na}, \mathrm{K}, \mathrm{PO}_{4} \mathrm{Cl}, \mathrm{SO}_{4}\right.$ and soil texture) between locations urban and rural area. The results of the $\mathrm{pH}$ showed that the soil of the agricultural lands close to the river Gharraf is tilted to the base where most values were more than 7 for both sites (Table 2). It is expected that the value of the pH of the Iraqi soil will be close to 8.0 as the Iraqi soil is calcareous. Table (2) shows that the values of electrical conductivity were high, indicating that the soil of this area is highly saline that the high values of electric conductivity are affected by high evaporation rates in the study sites. The results showed that calcium ions exceed the magnesium ions in the soil of the study area, which is due to the nature of the land passing through the river Gharraf. The difference in the calcium values between the study sites is due to the effect of temperature and other climatic factors such as precipitation, evaporation rates, and dust storms, which account for $40 \%$ calcium compounds due to the geological composition of the soil. Phosphate concentrations in agricultural soils were attributed to the addition of fertilizers and plant nutrients. However, they were close values in the study sites for high phosphorus susceptibility in relation to soil and not affected by repeated washing. The phosphorus component is difficult to move, and most phosphorus salts are $\mathrm{PO}_{4}$. The salinity of the sodium element in the study sites, in general, is evidence of the high rate of evaporation from the high-temperature rise. The salinity of the soil is due to sodium chloride salts in most of them. This is evident by the significant correlation between chloride and sodium. The concentration of the potassium $\mathrm{K}$ in both sites was clearly affected by evaporation as well as the use of agricultural fertilizers in the rural location compared to the location of 
the urban. The high concentration of chlorine $\mathrm{Cl}$ in the urban area is due to the quality of water and the nature of the soil. The high concentration of chlorine in the urban is due to the fact that this area is fed by the high saline Euphrates River. Measurement of soil texture controls chemical and physical properties such as ventilation, feeding, density and humidity. Both sites have mixed mud, sand or green ratios, which means that rural soil is highly nutrient-dense compared to urban soil. The results from this study are in agreement with [13-16]

Table 2: Effect of location on physical and chemical properties content of the study areas

\begin{tabular}{|c|c|c|c|}
\hline \multirow[t]{2}{*}{ Physiochemical properties } & \multicolumn{2}{|c|}{ Location } & \multirow[b]{2}{*}{ P-value } \\
\hline & Urban area & Rural area & \\
\hline $\mathbf{P H}$ & $7.89^{\mathrm{a}}$ & $7.46^{\mathrm{a}}$ & 0.06 \\
\hline Ec. dS.cm- ${ }^{1}$ & $10.93^{\mathrm{a}}$ & $8.51^{b}$ & 0.02 \\
\hline Mg ppm & $69.50^{b}$ & $117.25^{\mathrm{a}}$ & 0.00 \\
\hline Ca ppm & $560.00^{b}$ & $586.00^{\mathrm{a}}$ & 0.01 \\
\hline Na ppm & $391.00^{\mathrm{a}}$ & $373.00^{b}$ & 0.00 \\
\hline $\mathbf{K}$ ppm & $16.53^{\mathrm{a}}$ & $8.11^{\mathrm{b}}$ & 0.02 \\
\hline $\mathbf{P O}_{4} \mathrm{ppm}$ & $6.91^{\mathrm{a}}$ & $7.19^{\mathrm{a}}$ & 0.08 \\
\hline $\mathbf{S O}_{4} \mathrm{ppm}$ & $38.88^{\mathrm{a}}$ & $40.24^{\mathrm{a}}$ & 0.04 \\
\hline Cl ppm & $146.00^{\mathrm{a}}$ & $110.00^{b}$ & 0.00 \\
\hline Clay \% & $392^{\mathrm{a}}$ & $312^{b}$ & 0.01 \\
\hline Sand $\%$ & $148^{b}$ & $208^{\mathrm{a}}$ & 0.00 \\
\hline Silt $\%$ & $460^{b}$ & $480^{\mathrm{a}}$ & 0.02 \\
\hline
\end{tabular}

${ }^{\mathrm{a}-\mathrm{b}}$ Mean with different letters are significantly different $(\mathrm{P}<0.05)$

\section{CONCLUSION}

The results indicated that for both locations affected heavy metals content. The significant difference in, $\mathrm{Zn}, \mathrm{Cu}$ and $\mathrm{Pb}$ content in soil were found between the different environment. Our study provides a detailed examination of habitat location effects on potential of heavy metals content and physical and chemical properties in soil.

\section{REFERENCES}

[1] Oves, M., Saghir, K.M., Huda, Q.A., Nadeen, F.M. \& Almeelbi, T, 2016. Heavy Metals: Biological Importance and Detoxification Strategies. J. Bioremediat. Biodegrad, 7 (2): 1-15.

[2] Rakesh, S.M. \& Raju, N.S, 2013. Correlation of Heavy Metal Contamination with Soil Properties of Industrial Areas of Mysore, Karnataka, India by Cluster Analysis. Int. Res. J. Environment Sci, 2 (10): 22-27.

[3] Shaapera, U., Nnamonu, L.A. \& Eneji, I.S, 2013. Assessment of Heavy Metals in Rana esculenta Organs from River Guma, Benue State Nigeria. Am. J. Anal. Chem., 4 (09): 496-500.

[4] Alloway, B.J, 1995. Heavy Metals in Soils. Blackie Academic and Professional, Suffolk, England. 368 pp.

[5] Kabata-Pendias, A. P., H. , 2001. Trace Elements in Soil and Plants. Ed. Ke-3.

Boca Raton: CRC Press.

[6] Ribeyre, F. \& Boudou, A, 1994. Experimental Study of Inorganic and Methylmercury Bioaccumulation by Four Species of Freshwater Rooted Macrophytes from Water and Sediment Contamination Sources. Ecotoxicology and Environmental Safety, 28(3): 270-286.

[7] Whitehead, D. C, 2000. Nutrient Elements in Grassland: Soil-Plant-Animal Relationships. Cabi.

[8] Badri, M. A, 1984. Identification of Heavy Metal Toxicity Levels in Solid Wastes by Chemical Speciation. Conservation \& Recycling 7(2): 257-269.

[9] Duddridge, J. \& Wainwright, M, 1981. Heavy Metals in River Sediments-Calculation of Metal Adsorption Maxima Using Langmuir and Freundlich Isotherms. Environmental Pollution Series B, Chemical and Physical, 2(5): 387-397.

[10] Bryman, A. and Cramer, D. 2012. Quantitative data analysis with IBM SPSS 23: A guide for social scientists: Routledge

[11] Khairiah, J., Ding-Woei, Y., Habibah, J., Ahmed-Mahir, R., Aminah, A. \& Ismail, B, $2009 . \quad$ Concentration of Heavy Metals in Guava Plant Parts and Soil in the Sungai Wangi Plantation, Perak, Malaysia. International Journal Agriculture Research, 4: 310-316.

[12] Shrrog H.H, Wan Juliana, WA. \& Aminah, A, 2015. Content of heavy metals in plant and soil collected from urban and remote natural habitats. World Applied Sciences Journal, 33 (8): 1373-1379 .

[13] Abdulkadir A, 2017. Erosion Effect on Soil Physical Properties in Selected Farmlands in Gidan Kwano, Niger State. Journal of Horticulture and Plant Research, 2: 10-22

[14] Osakwe, S.A \& Okolie, LP. 2015. Physicochemical Characteristics and Heavy Metals Contents in Soils and Cassava Plants from Farmlands along A Major Highway in Delta State, Nigeria. J. Appl. Sci. Environ. Manage, 9 (4): 695-704.

[15] Yousif Algamal, 2015. Assessment and statistical study of physico-chemical properties of water quality in some local water treatment plants in Jeddah, Kingdom of Saudi Arabia. Advances in Applied Science Research, 6(7): 49-56.

[16] Olorunfemi I.O., Johnson T.F. \& Funke F.A, 2018. Soil physico-chemical properties and fertility status of longterm land use and cover changes: A case study in Forest vegetative zone of Nigeria. Eurasian J Soil Sci, 7 (2): 133-150. 